\title{
FIRST OBSERVATION OF THE YELLOW-BROWED WARBLER PHYLLOSCOPUS INORNATUS IN ROMANIA
}

\author{
Lucian-Eugen Bolboacă, Emanuel Ştefan Baltag, \\ Lucian Fasolă-Mătăsaru, Constantin Ion
}

\begin{abstract}
Balboacă L.-E., Baltag E. Ş., Fasolă-Mătăsaru L., Ion C. 2014. First observation of the Yellow-browed Warbler Phylloscopus inornatus in Romania. Ring 36: 45-49.

The Yellow-browed Warbler is a species of the Sylviidae family that breeds in Asia and winters in South East Asia and western Europe. In northern and north-western Europe it is considered one of the most numerous nocturnal migratory species from Siberia. In the southern and eastern part of the continent there are fewer observations of the presence of the species in passage or in winter. On $29^{\square}$ September 2013, during a ringing session in the southern part of the Danube Delta (Romania), we captured a juvenile individual of the Yellow-browed Warbler. This is the first record of the species in Romania.
\end{abstract}

Bolboacă L. E., "Vasile Goldiș" Western University of Arad, Bvd. Revoluției nr. 94-96, Arad, Romania, e-mail: lucian.bolboaca@gmail.com; Baltag E. Š., "Alexandru Ioan Cuza" University of Iaşi, Faculty of Biology, Department of Zoology, Bvd. Carol I, nr.20A, Iaşi, România, e-mail: baltag.emanuel@gmail.com; Fasolă-Mătăsaru L., "Alexandru Ioan Cuza" University of Iaşi, Faculty of Biology, Department of Zoology, Bvd. Carol I, nr. 20A, Iaşi, România, e-mail: lucian.fasola@gmail.com; Ion C., "Alexandru Ioan Cuza" University of Iaşi, Faculty of Biology, Department of Zoology, Bvd. Carol I, nr.20A, Iaşi, România, e-mail: costin_zoo@yahoo.com

Keywords: Yellow-browed Warbler Phylloscopus inornatus, first record, Romania

\section{INTRODUCTION}

The Yellow-browed Warbler Phylloscopus inornatus is a species of the Sylviidae family, of the order Passeriformes. It breeds in the temperate regions of Asia and is a winter guest in South East Asia (Cramp 1992, Del Hoyo et al. 2006) and, in smaller numbers, in western Europe (Folvik 1992).

During the nesting period, its characteristic habitat consists of broadleaf forests, especially birch, poplar and willow, but also spruce in the taiga and larch up to the 
subalpine zone, at altitudes of up to 3,500 meters (Baker 1997). The species leaves its breeding areas rapidly, between August and the beginning of September (Cramp 1992). During winter, the species can be observed in gardens, parks, open forests or shrubs, and avoids dense coniferous forests (Baker 1997).

In Europe, the Yellow-browed Warbler is a vagrant species, although an increasing number of individuals have been observed in recent years in the northern and north-western regions of the continent (Folvik 1992, Paal 2011), where the species is no longer listed as a rarity. Together with Pallas's Leaf Warbler Phylloscopus proregulus it is considered one of the two most numerous nocturnal migratory species from Siberia (Paal 2011). Its first observation in Norway was recorded in 1937 and the second in 1950, and by 1970 only 11 observations had been recorded. In 1975 it was no longer considered a national rarity and by 1990317 individuals had been recorded, of which two belonged to the subspecies Phylloscopus inornatus humei (Folvik 1992). Although it has been noted every year in Norway since 1972, most recordings took place in 1985 (64 observed individuals), 1988, 1986 and 1981 (Folvik 1992). In Great Britain 9093 observations of the Yellow-browed Warbler were made between 1958 and 2003, most of them after 1985, with only 2648 observations taking place before 1985 (Fraser and Rogers 2006). Up to 2003, 911 sightings occurred in Sweden (Strid 2004), 829 in France (Frémont et al. 2005), about 700 in Ireland (Milne 2004) and 422 in Denmark (de Juana 2008). Up to 2014 around 60 individuals were caught on the Polish Baltic coast (P. Busse pers. comm.). Fewer observations were recorded in southern Europe: Spain - 42, Portugal - 10 and Gibraltar - 3 (de Juana 2008). Closer to Romania, by the end of 2013 there had been 26 confirmed observations in Hungary (www.rarebirds.hu), three in Ukraine and one in Croatia (www.tarsiger.com). Another was caught in Croatia in the beginning of October 2014 (P. Busse pers. comm.).

\section{MATERIALS AND METHODS}

A ringing session took place between September 28th and October 2nd 2013, near Vadu, Constanta County. This area is located in the Dobrogea region, in the southern part of the Danube Delta Biosphere Reserve $\left(44^{\circ} 26^{\prime} \mathrm{N}, 28^{\circ} 43^{\prime} \mathrm{E}\right)$ in the south-eastern Romania, on the western shore of the Black Sea. This area is known as an important migration spot because of its geographic position: the southern part of the Danube Delta Biosphere Reserve, where it narrows to a strip of land (Török 2002). Six 12 metre long mist nets were used for bird capture in the beach area. The chosen habitat consists of sandy substrate with shrubs of silver berry Elaeagnus angustifolia and common sea-buckthorn Hippophaë rhamnoides. Among the herbaceous vegetation, a great variety of associations can be distinguished according to soil humidity and salinity: Secalietum silvestre and Agropyretum elongati on higher levees, AleuropoPuccinellietum limosae, Juncetum maritimii, Aleuropetum littoralis on lower grounds and Salicorinietum europaeae or Suedetum maritimae on lower areas with high salinity (Török 2002). On September 29व, because of bad weather conditions, the mist nets were open for only four hours. Twenty five birds were captured during this time. The 
captured birds were measured according to the methodology described by Svenson (1992).

\section{RESULTS AND DISCUSSION}

The Yellow-browed Warbler Phylloscopus inornatus was one of the species that was captured (Fig. 1). The bird was ringed and eight biometric measurements were taken: total length - $117 \mathrm{~mm}$, wing length (maximum chord) - $54 \mathrm{~mm}$, third primary - $41 \mathrm{~mm}$, tail length $-38 \mathrm{~mm}$, tarsus length/width $-17.3 / 1.1 \mathrm{~mm}$, fat score -1 and body mass $-6.5 \mathrm{~g}$.

The bird was smaller than the Chiffchaff Phylloscopus collybita. It was greenishgrey on the upper body and whitish underneath, with brown legs. It had a lightyellow, long and prominent eyebrow with a black stripe under it. The wings had a wide, light-coloured stripe and a secondary shorter stripe. The tertials were darkcoloured in the centre and light-coloured on the edges. More details can be observed in the photo (Figure 1). The shape of the tail feather suggested a juvenile individual (Busse 1984). Regarding sex identification, Phylloscopus inornatus does not show sexual dimorphism in their colouration (Svensson 1992) and the measurements of this individual do not clearly indicate its sex.

Most Yellow-browed Warbler individuals in mainland Europe are captured in autumn, from September to November (Mitchell and Young 1997). In Estonia, the first individuals are captured in September and the peak of their occurrence is in the

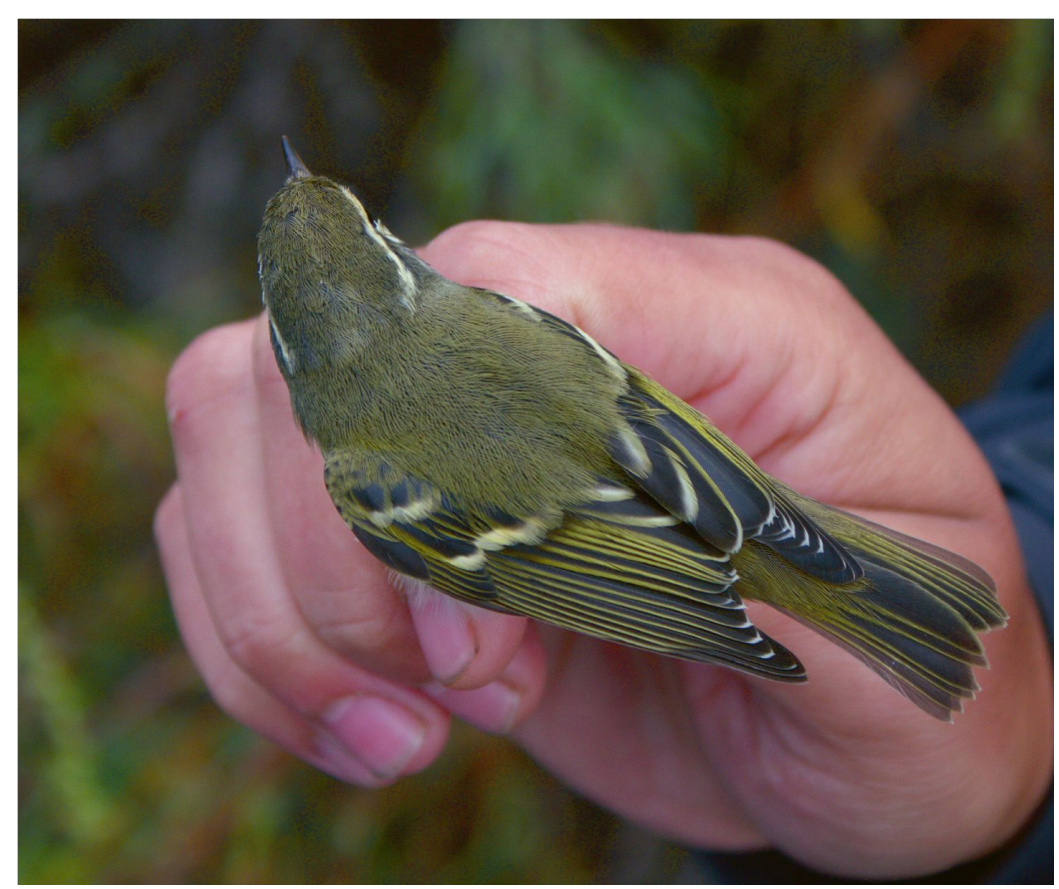

Fig. 1. Yellow-browed individual caught 
first ten days of October. Also in Latvia and Finland most birds are captured at the beginning of October. In the British Isles most captured birds are recorded in the first half of October (Dymond et al. 1989, Wernham et al. 2002), and in France between the $20^{\square}$ and $25^{\square}$ of October (Dubois et al. 2000), as on the Iberian Peninsula (De Juana 2008). To the southwest, in the Canary Islands, the first recordings begin in December (De Juana 2008). On the islands of the Central and Eastern Mediterranean Sea most captures occur between October and November (Cambi and Cambi, 1986). In Ukraine, birds were captured between 10th and 19 ${ }^{\square}$ October (Poluda et al. 2004, www.tarsiger.com), in Croatia at the end of October (www.tarsiger.com) and in Hungary between $23^{\square}$ September and $4^{\square}$ November, with most of the individuals captured in mid-October (www.rarebirds.hu). The capture of the Yellow-browed Warbler individual on the Chituc levee occurred before the peak autumn migration of the species in south-eastern mainland Europe in mid-October.

The importance of this capture resides in the fact that this is the first documented record of this species on Romanian territory. Later, in October 2013, another Yellowbrowed Warbler individual was observed near the city of Tulcea (E. Todorov, pers. comm.). In 2014, another bird of the same species was captured on Chituc Ground (www.rombird.ro/en) by the members of Milvus Group (Romania), and one was observed in the south-western part of the country, near Timişoara (www.rombird.ro/en).

\section{ACKNOWLEDGEMENTS}

We wish to thank the team members that were present at the moment of capture: Mr. Eugen Petrescu of the Romanian Ornithological Society and Gheorghe Zaharia.

\section{REFERENCES}

Baker K. 1997. Warblers of Europe, Asia, and North Africa. Princeton: Princeton University Press, 289-290.

Busse P. 1984. Key to sexing and ageing of European Passerines. Beitr. Naturk. Niedersachsens 37, Suppl.: 71.

Cambi D., Cambi L. 1986. Migrazione e fenologia del Lui forestiero, Phylloscopus inornatus, in Italia e nell'Europa meridionale. Riv. ital. Orn. 56: 79-94.

Cramp S. (Ed.) 1992. The Birds of the Western Palearctic, vol. VI. Oxford University Press. Oxford.

De Juana E. 2008. Where do Palla's and Yellow-Browned Warblers (Phylloscopus proregulus, Ph. Inornatus) go after visiting Northwest Europe in autumn? An Iberian perspective. Ardeola 55(2): 179-192.

Del Hoyo J., Elliott A., Christie D. A. 2006. Handbook of the Birds of the World. Vol. 11, Old world Flycatchers to Old World Warblers. Lynx Edicions. Barcelona.

Dubois P. J., Lemarechal P., Olioso G., Yésou P. 2000. Inventaire des oiseaux de France. Avifaune de la France métropolitaine. Nathan. Paris.

Dymond J. N., Fraser P. A., Gantlett S. J. M. 1989. Rare birds in Britain and Ireland. T \& AD Poyser. Calton.

Folvik A. 1992. Norwegian records of Yellow - browed Warblers Phylloscopus inornatus. Fauna norv. Ser. C. Cinclus 15: 31-36.

Fraser P. A., Rogers M. J. 2006. Report on scarce migrant birds in Britain in 2003. Part 2: Shorttoed Lark to Little Bunting. British Birds 99: 129-147.

Frémont J.-Y., Le Chn 2005. Les oiseaux rares en France en 2003. Ornithos 12: 2-45. 
Milne P. 2004. Fifty-first Irish Bird Report, 2003. Irish Birds 7: 567.

Mitchell D., Young S. 1997. Photographic handbook of the rare birds of Britain and Europe. New Holland. London.

Paal U. 2011. Reports on Occurrence of Yellow - browed Warbler Phylloscopus inornatus and Pallas-s Leaf Warbler P. proregulus in Estonia from 1973-2010. Hirundo 24: 13 - 17.

Poluda A. M., Diadicheva E. A., Kivganov D.A., Korzyukov A.I., Omelchuk I.Y. 2004. Registrations of Yellow-browed Warbler (Phylloscopus inornatus) in Ukraine. Vestnik Zoologii. 38 (2): 78. (in Russian).

Strid T. 2004. Fagelrapport 2003. Vår Fågelvärld, Suppl. No. 42: 99-169.

Svensson L. 1992. Identification Guide to European Passerines. Stockholm.

Török Z. 2002. Chituc marine levee. Petarda No. 10. Ed. Aves. Tulcea: 8, 10.

Wernham C. V., Toms M. P., Marchant J. H., Clark J. A., Siriwardena G.M., Baaillie S. R. (Eds.) 2002. The migration atlas: movements of the birds of Britain and Ireland. T \& AD. Poyser. London.

www.rarebirds.hu - Downloaded at 12 Sept 2014.

www.rombird.ro/en/obd/5878/index?from $=0 \&$ fromt $=$ fooldal\&fromid $=0-$ Downloaded at 29 Sept.2014

www.tarsiger.com - Downloaded at 12 Sept 2014. 